\title{
Alterations in gene expression in hamster diaphragm after emphysema and lung volume reduction surgery
}

\author{
V. Reynders*, E. Marchand*, G. Gayan-Ramirez*, P. De Leyn\#, G. Verhoeven`, M. Decramer*
}

Alterations in gene expression in hamster diaphragm after emphysema and lung volume reduction surgery. V. Reynders, E. Marchand, G. Gayan-Ramirez, P. De Leyn, G. Verhoeven, M. Decramer. (C) ERS Journals Ltd 2002.

ABSTRACT: The authors have demonstrated previously that emphysema and lung volume reduction surgery (LVRS) resulted in a significant shift of type IIx/b to type IIa fibres in the diaphragm of hamsters with elastase-induced emphysema. To explore the mechanisms leading to this fibre switching, the mRNA expression of the myogenic regulatory factors, the inhibitors of DNA binding proteins (Id-proteins) and insulin-like growth factor-I were examined.

Ribonucleic acid was extracted from the diaphragm of control, emphysematous, emphysematous and sham operated and LVRS hamsters and subjected to reverse transcriptase polymerase chain reaction.

Compared to control, the ratio MyoD to myogenin declined with emphysema, sham and even more after LVRS, due to a decrease in MyoD mRNA and an increase in myogenin mRNA. Similarly, compared to control, Id-1 protein mRNA levels decreased significantly in sham and even more in LVRS. Id-2 protein mRNA levels decreased in all groups, but reached statistical significance in LVRS only, compared to control.

In conclusion: 1) the reduced MyoD/myogenin ratio may be the mechanism of the shift to a slower fibre type, 2) the decreased MyoD/myogenin ratio in lung volume reduction surgery animals suggests that lung volume reduction surgery enhances rather than decreases the load placed on the diaphragm and 3) the observed down-regulation of the inhibiting factors may facilitate the diaphragm adaptation to overload.

Eur Respir J 2002; 19: 1064-1071.

Lung volume reduction surgery (LVRS) has become a therapeutic option for patients with endstage emphysema, as it appears to improve pulmonary function, quality of life and respiratory muscle function $[1,2]$. However, the extent to which LVRS may affect respiratory muscle function at the molecular level, still remains to be determined. In a recent study, the authors demonstrated that LVRS did not improve diaphragmatic contractile properties or morphology in hamsters with elastase-induced emphysema [3]. Indeed, both emphysema and LVRS were associated with a significant shift from type IIx/b to type IIa fibres [3]. No differences between emphysema and LVRS were present. The fibre shift in this study was similar to the observed fibre shift in the diaphragm of patients with severe chronic obstructive pulmonary disease (COPD) [4].

The myogenic transcription factors MyoD, myogenin, MRF-4 and myf-5, which belong to the family of basic helix-loop-helix (bHLH) proteins and which are skeletal muscle-specific, can stimulate and modulate the transcription of muscle-specific genes and are thus able to contribute to muscle plasticity $[5,6]$.
*Respiratory Muscle Research Unit, Laboratory of Pneumology, ${ }^{\#}$ Thoracic Surgery Division and Laboratory for Experimental Medicine and Endocrinology, University Hospitals, Katholieke Universiteit Leuven, Leuven, Belgium.

Correspondence: M. Decramer, Respiratory Division, University Hospital, Herestraat 49, B-3000 Leuven, Belgium. Fax: 3216347126

E-mail: marc.decramer@uz.kuleuven. ac.be

Keywords: Emphysema, Id-proteins, IGF-I, muscle plasticity, myogenic regulatory factors, RT-PCR

Received: November 222001

Accepted after revision January 182002

The study was supported by Fonds voor Wetenschappelijk OnderzoekVlaanderen grant \#G.0175.99 and Katholieke Universiteit Leuven Research Foundation grant \#OT98/27. G. Gayan-Ramirez is a postdoctoral fellow of the Fonds voor Wetenschappelijk Onderzoek-Vlaanderen.
Their role in muscle atrophy, hypertrophy and fibre shift has been demonstrated in rats and in mice [7-9].

Conversely, the inhibitors of DNA-binding proteins (Id-proteins; Id-1 to Id-4) are a subfamily of the HLH transcription factors that lack the basic region essential for DNA binding and activation of transcription. These proteins are expressed in a variety of tissues including skeletal muscle. They act as dominant negative regulators of the bHLH transcription factors and thereby inhibit gene transcription [10, 11]. Indeed, the muscle atrophy and fibre shift caused by denervation was associated with an important increase in Id-1 messenger ribonucleic acid (mRNA) in rats $[12,13]$.

Moreover, insulin-like growth factor (IGF)-I is well known to stimulate the differentiation and fusion of skeletal muscle satellite cells to adjacent myocytes $[14,15]$. IGF-I is not only produced in the liver, but also in a range of extrahepatic tissues such as myoblasts and myocytes from skeletal muscles. Upregulation of local IGF-I has been shown to be involved in skeletal muscle hypertrophy $[16,17]$ and muscle fibre-type conversion [14], while down-regulation 
was reported to be associated with muscle atrophy [18].

This study was designed to attempt to obtain insight into the mechanisms by which emphysema and LVRS led to the earlier-mentioned fibre-type shift. To this end, the mRNA levels of the myogenic regulatory factors, the Id-proteins and IGF-I were examined by semiquantitative reverse transcriptase polymerase chain reaction (RT-PCR) in a hamster model.

\section{Methods}

\section{Induction of emphysema}

A total of 41, 10-week-old, male Syrian hamsters underwent transoral tracheal intubation with a 16-gauge catheter (Insythe-W catheter; Becton Dickinson, Madrid, Spain) after being anaesthetized with sodium pentobarbital (Nembutal; Sanofi Santé Animale Benelux, Brussels, Belgium; $45 \mathrm{mg} \cdot \mathrm{kg}$ body weight $^{-1}$ (bw) i.p.). Hamsters were instilled on a random basis with either porcine pancreatic elastase (Sigma $40 \mathrm{U}$ elastase $\cdot 100 \mathrm{~g} \cdot \mathrm{bw}^{-1}$ in a volume of $0.4 \mathrm{~mL}$ sodium chloride $0.9 \% \cdot 100 \mathrm{~g} \cdot \mathrm{bw}^{-1}, \mathrm{n}=30$ ) or $0.4 \mathrm{~mL}$ sodium chloride $0.9 \% \cdot 100 \mathrm{~g} \cdot \mathrm{bw}^{-1}$ (control animals: C). Animals were kept in cages and provided with standard laboratory chow and water as required. The Animal Experiments Committee of the Medical Faculty of the Katholieke Universiteit Leuven approved the study.

\section{Surgical procedure}

Four months after intratracheal elastase instillation, the emphysematous animals were randomly divided into three groups: 1) emphysematous hamsters $(n=7)$, 2) emphysematous and sham operated hamsters $(n=7)$ and 3) emphysematous and LVRS hamsters $(n=16)$. LVRS hamsters underwent a sternotomy, the right pleura was incised and drawn out of the thoracic cage. The two arms of a linear cutter (ETS-Flex $35 \mathrm{~mm}$; Ethicon Endo-Surgery, Inc., Cincinnati, OH, USA) loaded with thin staples used in human vascular surgery (Endopath TR35W; Ethicon Endo-Surgery, Inc., Cincinnati, OH, USA) were slid around the lung before the stapler cutter was activated. The same procedure was performed for the left lung. The procedure has been described in detail by MARCHAND et al. [3].

The resection, estimated visually, aimed at removing $25-30 \%$ of the lung volume. The animals of the sham group underwent the same procedure except for the lung resection.

Six hamsters of the LVRS group and one sham animal died soon after the end of the surgical procedure. Three other animals of the LVRS group died a few days after surgery. Autopsy revealed an important amount of blood in the pleural cavities in all cases. Finally, the sham and LVRS groups contained six and seven animals, respectively. The saline-instilled hamsters served as control hamsters and were not subjected to any surgical procedure $(\mathrm{n}=11)$.

\section{Evaluation of emphysema: functional residual capacity measurements}

Nine weeks after surgery (and at an equivalent age for the control animals), functional residual capacity (FRC) measurements were performed using a setting modified by Koo et al. [19]. Rather than using a constant volume plethysmograph, a flow plethysmograph was used. Accordingly, a pneumotachograph (Hans Rudolph 8420B; Hans Rudolph Inc., Kansas City, MO, USA) connected to a differential pressure transducer (MP45; Validyne, Northbridge, CA, USA; range $\pm 2 \mathrm{cmH}_{2} \mathrm{O}$ ) was placed in the wall of a body box and volume changes were calculated by integration of the flow signal. All volume measurements were performed at least in triplicate. These were averaged for statistical analysis.

\section{RT-PCR procedure for the measurement of IGF-I,} myogenic factor and Id-protein $m R N A$ levels

RNA extraction. After completion of the lung-volume measurements, the animals were mechanically ventilated and the diaphragm was carefully removed en bloc after laparotomy. The diaphragm was blotted, weighed, frozen in liquid nitrogen and stored at $-80^{\circ} \mathrm{C}$. Total ribonucleic acid (RNA) was isolated using a modified guanidium isothiocyanate-cesium chloride method [20]. Approximately $0.15 \mathrm{~g}$ of tissue was transferred into a solution containing $50 \%$ (weight/volume) guanidium thiocyanate, $25 \mathrm{mM}$ ethylenediamine tetraacetic acid (EDTA), 0.5\% lauryl sarcosine and $0.1 \mathrm{M}$ 2-mercaptoethanol and homogenized with an Ultra-Turrax homogenizer (Janke \& Kunkel, Germany). The homogenate was layered on top of a solution containing $5.7 \mathrm{M} \mathrm{CsCl}$, $25 \mathrm{mM}$ sodium acetate ( $\mathrm{pH} 5.0$ ) and $10 \mathrm{mM}$ EDTA. After ultracentrifugation at $20^{\circ} \mathrm{C}$ in a SW41 rotor (Beckman, Germany) at $100,000 \times g$ for $\sim 16 \mathrm{~h}$, the supernatant was removed and the RNA pellet was dissolved in water. The RNA was precipitated by adding one-tenth volume of sodium acetate $(3 \mathrm{M}$, $\mathrm{pH}=5.2$ ) and 2.5 volumes of absolute ethanol. The samples were stored at $-20^{\circ} \mathrm{C}$ during the night. The next day, the RNA was rinsed with $70 \%$ ethanol, vacuum dried and redissolved in water. The quantity of RNA was determined by optical density (OD) at $260 \mathrm{~nm}$ and $280 \mathrm{~nm}$.

Reverse transcriptase reaction. Total RNA $(2.5 \mu \mathrm{g})$ was subjected to oligo(deoxythymidine)-primed firststrand complementary deoxyribonucleic acid (cDNA) synthesis in a volume of $20 \mu \mathrm{L}$ following the instructions of the GibcoBRL-kit (THERMOSCRIPT ${ }^{\mathrm{TM}} \mathrm{RT}$ PCR System, Life Technologies N.V., Merelbeke, Belgium).

$P C R$. All applied primers were designed using the Vector NTI software and were produced by 


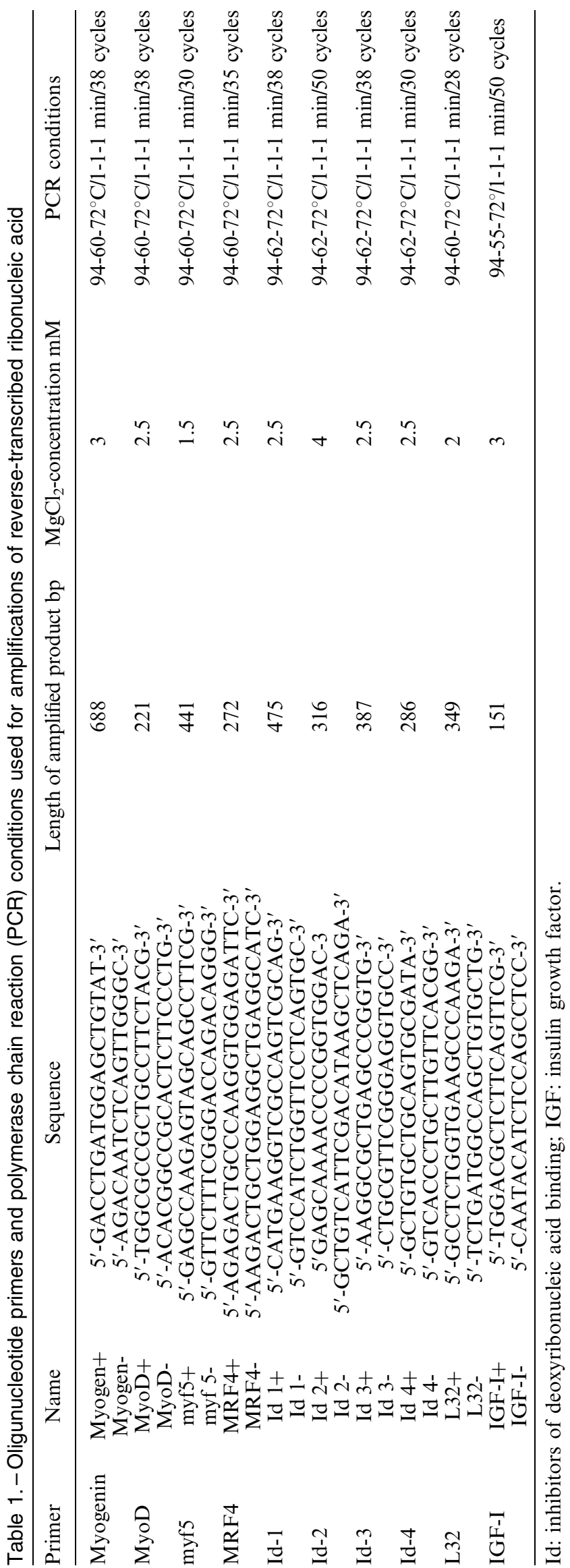

GibcoBRL (GibcoBRL Custom Primers, Life Technologies, Scotland, UK). A $2-\mu \mathrm{L}$ portion of the firststrand cDNA sample was used for a $50 \mu \mathrm{L}$ polymerase

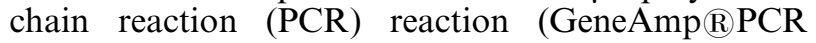
Core Reagents kit; Perkin Elmer, Lennik, Belgium) under the conditions specified in table 1 . The number of PCR cycles was adjusted to avoid saturation of the amplification system. Also the optimal $\mathrm{MgCl}_{2}-$ concentration and annealing temperature was established for each primer. PCR products were identified by their sizes. Amplification products were analysed by electrophoresis on acrylamide gel $(6 \% \mathrm{w} / \mathrm{v})$. Gels were stained with Vistra Green (Amersham Life Science, Buckinghamshire, UK) and the fluorescence intensity of the bands was quantified by means of a PhosphorImager model 425 (Molecular Dynamics, Sunnyvale, CA, USA) and ImageQuant software. Band intensities of the amplified fragments were normalized to the corresponding L32 (house-keeping gene) amplification signals. For each primer, the PCR procedure was performed in duplicate, at the very least.

\section{Statistical analysis}

Comparisons among groups were performed using a one-way analysis of variance. Differences between means were assessed using the Duncan post-hoc test for all paired comparisons. Data are expressed as means \pm SD.

\section{Results}

\section{Body and diaphragm weight}

Body weight was comparable between groups at the time of instillation (pooled values: $130 \pm 7 \mathrm{~g}$ ). However, at the time of surgery, body weight was significantly lower in LVRS hamsters compared to sham animals $(\mathrm{p}<0.01)$ (table 2$)$. Compared to the time of surgery, body weight of LVRS hamsters was significantly lower at the time of dissection $(p<0.05)$.

At the time of dissection, the mean diaphragm weight was $0.26 \pm 0.02,0.23 \pm 0.03,0.23 \pm 0.02$ and $0.21 \pm$ $0.03 \mathrm{~g}$ for control, emphysematous, sham and LVRS hamsters, respectively. When normalized for body

Table 2. - Body weight (bw) and diaphragm weight

\begin{tabular}{cccll}
\hline & Control & Emphysema & Sham & LVRS \\
\hline $\begin{array}{c}\text { Body weight g } \\
\text { Instillation }\end{array}$ & $129 \pm 11$ & $134 \pm 11$ & $137 \pm 7$ & $122 \pm 9$ \\
$\begin{array}{c}\text { Surgery } \\
\text { Dissection }\end{array}$ & $169 \pm 25^{* *}$ & $152 \pm 13^{*}$ & $162 \pm 12^{* *}$ & $146 \pm 5$ \\
$\begin{array}{c}\text { Diaphragm } \\
\text { Weight g }\end{array}$ & $0.26 \pm 0.02$ & $0.23 \pm 0.03$ & $0.23 \pm 0.02$ & $0.21 \pm 0.03$ \\
Weight/ & $0.15 \pm 0.01$ & $0.15 \pm 0.02$ & $0.15 \pm 0.01$ & $0.16 \pm 0.02$ \\
b.w. \% & & & & \\
\hline
\end{tabular}

Data are presented as mean \pm SD. LVRS: lung volume reduction surgery. *: $\mathrm{p}<0.05$ compared to LVRS; **: $\mathrm{p}<0.01$ compared to LVRS. 


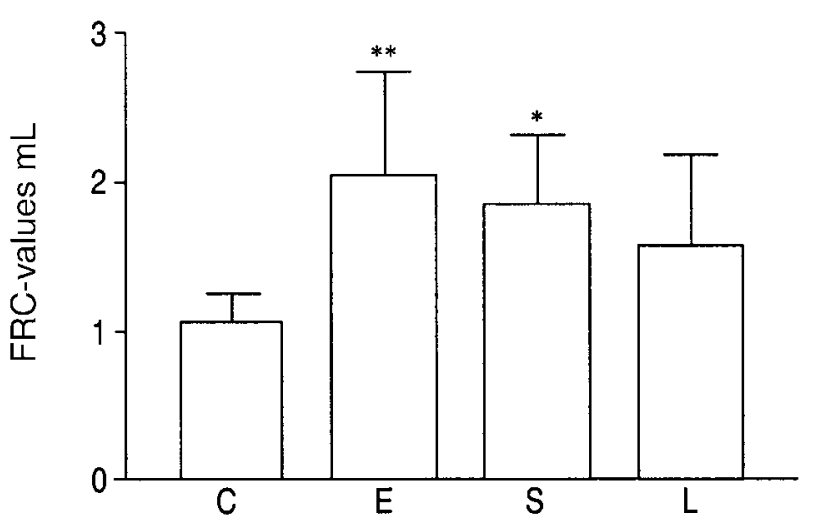

Fig. 1.-Functional residual capacity (FRC) values for control (C), emphysema (E), emphysema and sham operated (S) and lung volume reduction surgery $(\mathrm{L})$. Data are presented as mean $\pm \mathrm{SD}$. *: $\mathrm{p}<0.05$ compared to $\mathrm{C} ;{ }^{* *}: \mathrm{p}<0.01$ compared to $\mathrm{C}$.

weight, diaphragm weight was equal in the four groups (table 2).

\section{Functional residual capacity measurements}

Compared to control $(1.05 \pm 0.17 \mathrm{~mL})$, FRC was $2.05 \pm 0.69(\mathrm{p}<0.01), 1.84 \pm 0.46(\mathrm{p}<0.05)$ and $1.58 \pm$ $0.60 \mathrm{~mL}$ (NS) for emphysematous, sham and LVRS animals, respectively (fig. 1). FRC was thus increased by $94 \%$ after emphysema, by $75 \%$ in sham and by $50 \%$ in LVRS animals compared to control. So, LVRS reduced the FRC values of the emphysematous hamsters by $23 \%$.

\section{PCR experiments}

All data reported in this section are related to the results obtained after normalization with the data obtained with L32 (fig. 2).

\section{Changes in $m R N A$ levels of the myogenic factors}

MyoD and myogenin. Primers were designed to amplify a $221 \mathrm{bp}$ and $688 \mathrm{bp}$ fragment of MyoD and myogenin, respectively. Compared to control, MyoD mRNA levels were decreased in sham $(-28 \%, \mathrm{NS})$ and even more so in LVRS animals $(-58 \%, \mathrm{p}<0.05)$, while no changes were observed in emphysematous hamsters (fig. 3). Also a significant decrease in MyoD mRNA expression was observed after LVRS compared to emphysema (-59\%,

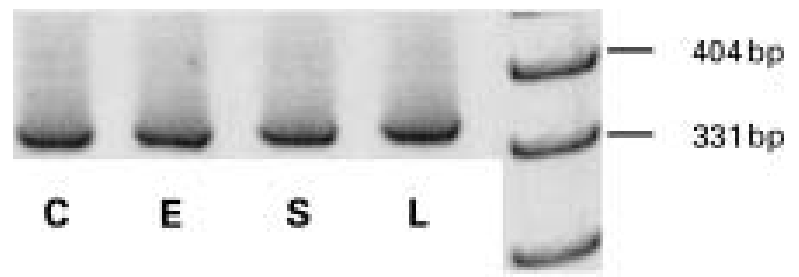

Fig. 2.-RT-PCR amplification products of L32 (349 bp) of the hamster diaphragm in control (C), emphysema (E), emphysema and sham (S) and lung volume reduction surgery (L).

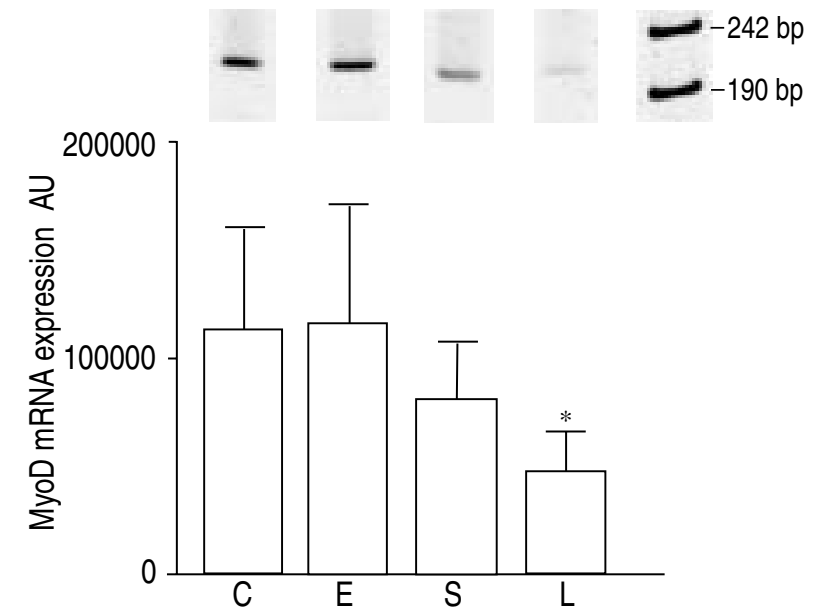

Fig. 3.-RT-PCR amplification products $(221 \mathrm{bp})$ and levels of MyoD mRNA of the hamster diaphragm in control (C), emphysema (E), emphysema and sham operated (S) and lung volume reduction surgery hamsters (L). Data are corrected with L32 values and presented as mean \pm SD. *: $\mathrm{p}<0.05$ compared to $\mathrm{C}$ and $\mathrm{E}$.

$\mathrm{p}<0.05)$. Conversely, myogenin showed a nonsignificant increase after emphysema $(+62 \%)$, sham $(+34 \%)$ and LVRS $(+33 \%)$, compared to control (fig. 4). As a consequence, compared to control, the ratio MyoD to myogenin decreased in emphysematous animals $(-29 \%$, NS) and significantly in sham $(-45 \%, \mathrm{p}<0.05)$ and LVRS hamsters $(-68 \%, \mathrm{p}<0.01)$ (fig. 5). This ratio decreased progressively from emphysema to sham and LVRS.

$m y f-5$. A $441 \mathrm{bp}$ fragment of the myf-5 mRNA was obtained after RT-PCR using the specific primers. No obvious changes in myf-5 expression were seen between the four groups.

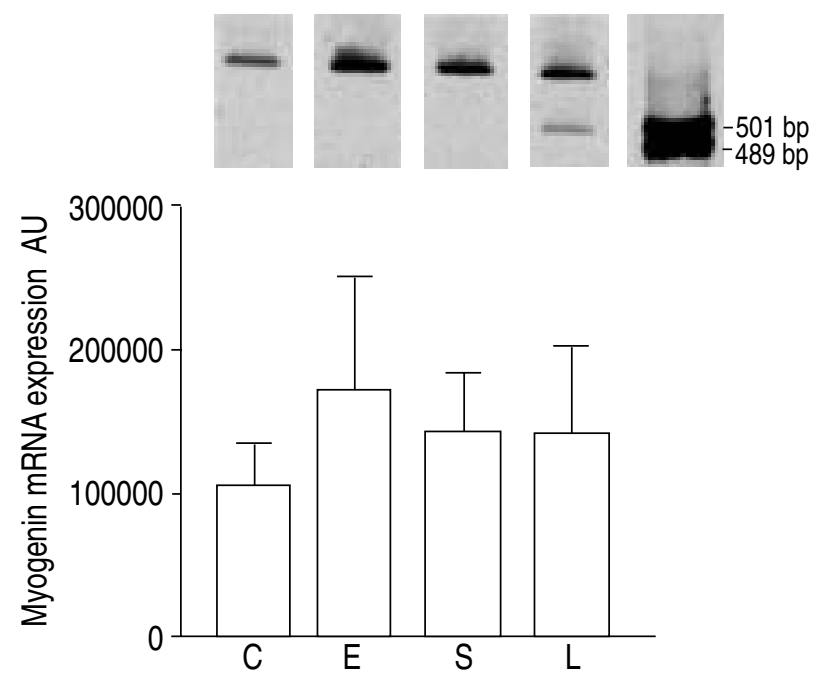

Fig. 4.-RT-PCR amplification products (688 bp) and levels of myogenin mRNA of the hamster diaphragm in control (C), emphysema (E), emphysema and sham operated (S) and lung volume reduction surgery hamsters (L). Data are corrected with $\mathrm{L} 32$ values and presented as mean $\pm \mathrm{SD}$. 


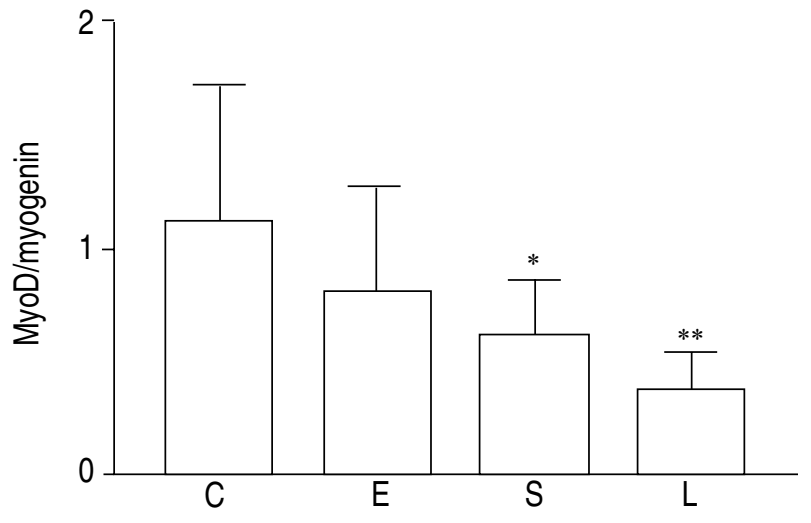

Fig. 5.-The MyoD/myogenin ratio. C: control; E: emphysema; S: emphysema and sham operated; L: lung volume reduction surgery. Data are presented as mean \pm SD. ${ }^{*}: \mathrm{p}<0.05$ compared to $\mathrm{C} ; * *: \mathrm{p}<0.01$ compared to $\mathrm{C}$.

MRF4. A fragment of $272 \mathrm{bp}$ was amplified for MRF4. Similarly as for myf-5, no significant changes in MRF4 mRNA levels were observed whatever the condition.

\section{Changes in $m R N A$ levels of Id-proteins}

Id-protein 1. Compared to control, Id-1 mRNA levels (475 bp fragment) tended to decrease progressively in emphysema $(-23 \%, \mathrm{NS})$, sham $(-34 \%, \mathrm{p}<0.05)$ and LVRS animals $(-48 \%, \mathrm{p}<0.01)$ (fig. 6a).

Id-protein 2. Correspondingly, compared to control, the Id-2 expression levels (316 bp fragment) decreased similarly after emphysema $(-32 \%)$ and sham $(-33 \%)$ and reached statistical significance in LVRS $(-37 \%$, $\mathrm{p}<0.05$ ) (fig. 6b).

Id-protein 3. For Id-3, the expression levels of the $387 \mathrm{bp}$ amplified fragment remained unchanged in all groups.

Id-protein 4. Id-4 expression levels fell below the detection limit of the technique.

\section{Changes in $m R N A$ levels of IGF-I}

Compared to control, IGF-I expression levels (151 bp fragment) tended to decrease with $44 \%, 74 \%$ and $59 \%$ in emphysematous, sham and LVRS animals, respectively, without reaching statistical significance.

\section{Discussion}

The present study showed that: 1) the MyoD/ myogenin ratio declined with emphysema and sham and even more so after LVRS, due to a decrease in the MyoD mRNA levels and an increase in myogenin mRNA and 2) emphysema and sham induced a reduction in Id-1 and Id-2 mRNA levels of the
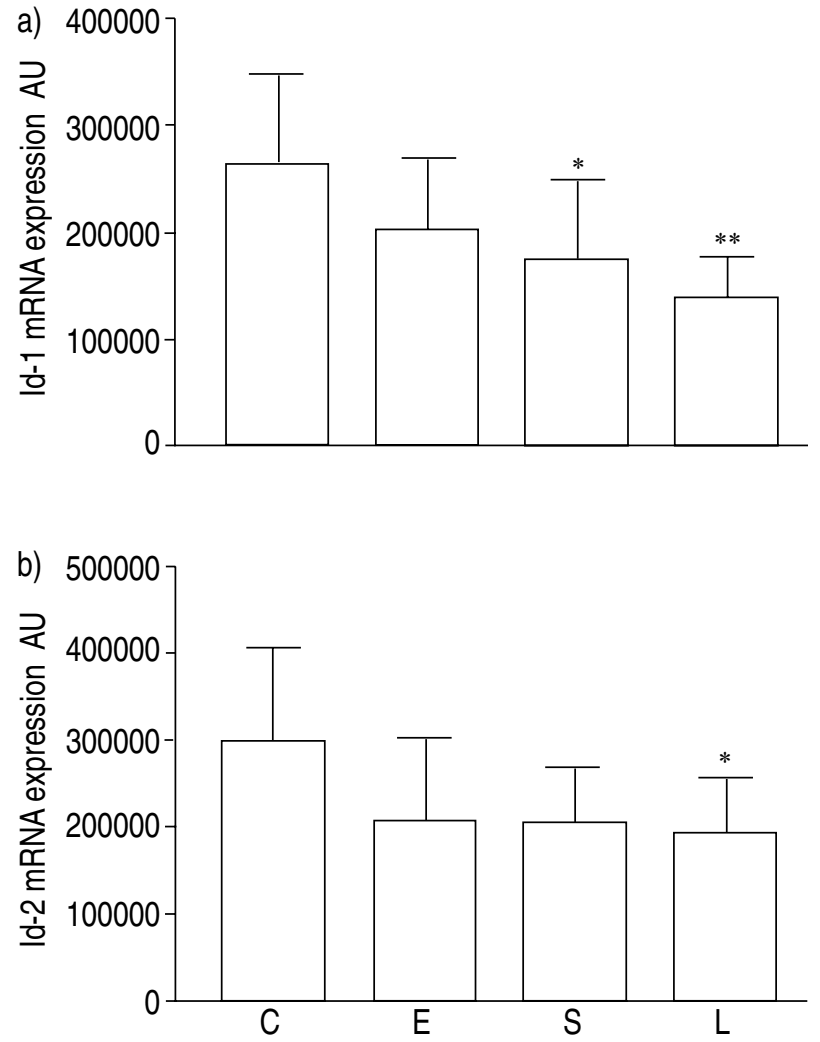

Fig. 6.-RT-PCR amplification levels of a) Id-1 and b) Id-2 mRNA of the hamster diaphragm in control (C), emphysema (E), emphysema and sham (S) and lung volume reduction surgery (L) hamsters. Data are corrected with L32 values and presented as mean \pm SD. *: $\mathrm{p}<0.05$ compared to $\mathrm{C} ;{ }^{* *}: \mathrm{p}<0.01$ compared to $\mathrm{C}$.

diaphragm; this decrease was even more pronounced after LVRS.

It should be noted however, that this model has significant limitations. The authors performed LVRS in a well-known model of emphysema [21]. Intratracheal elastase is known to induce a diffuse type of emphysema which closely mimicks the panlobular emphysema associated with $\alpha_{1}$-antitrypsin deficiency [21]. Accordingly, it differs from the characteristic smoking-induced centrilobular emphysema, which preferentially develops in the upper lobes. Although elastase-induced emphysema in hamsters is not associated with an increased resistive work of breathing [22], the dramatic alterations in the geometry of the inspiratory muscles clearly increases the load these muscles face at the muscle fibre level. Accordingly, the model of elastase-induced emphysema appears suitable to address different questions related to the physiological basis of alterations occurring in respiratory mechanics and respiratory muscle function after LVRS.

The body weight of the sham-operated hamsters did not change after surgery, while body weight of the LVRS hamsters decreased by $9 \%$. This weight loss may indicate that LVRS induced some catabolic reactions in the hamsters, which can explain the observed differences in mRNA expression among sham and LVRS animals. The observed mRNA down-regulation after sham-operation was more 
pronounced after LVRS, which could partially result from the catabolic state in the hamster.

FRC measurements revealed that the degree of emphysema obtained in the present study were somewhat less than in a previous study by the authors [3]. However, even nine weeks after LVRS, significant changes in mRNA levels of some of the transcription factors described earlier could still be observed, despite a moderate sample size and a lower level of emphysema. To the best of the authors knowledge, this is the first study in which the expression of the myogenic regulatory factors and the Id-proteins were measured in the diaphragm in an animal model of emphysema. Furthermore, samples could not be taken at different points in time due to experimental conditions.

The authors' previous study demonstrated a shift of type IIx/b to type IIa fibres in the diaphragm of emphysematous and LVRS-treated hamsters with ATPase staining [3]. Similar results were obtained in the scalenus medius of emphysematous hamsters, where an increase in the relative amount of MHCIIa and type IIa fibres and a decrease for MHCIIx and type IIx fibres were reported [23]. Furthermore, the fibre shift towards a slower profile in this study is comparable with the shift observed by LEVINE et al. [4], who found an increased proportion of slow fatigue-resistant type I fibres and a lower percentage of type IIa and IIb fibres in the diaphragm of patients with severe COPD. Along the same lines, a negative linear correlation between forced expiratory volume in one second (FEV1) and the proportion of slow myosin of the diaphragm was demonstrated in COPD patients [24]. Since COPD leads to a chronically increased load and energy expenditure for the respiratory muscles, an increased resistance for fatigue was expected as discussed in an earlier study by the authors [3]. In actual fact, there is no data on diaphragm fibre composition after LVRS in patients. In the present study, the diaphragm fibre composition was not actually measured but the data observed in the authors' previous study was referred to [3].

The MyoD/myogenin ratio decreased progressively after emphysema, sham and even more after LVRS in the present study, due to a decrease in the MyoD mRNA levels and an increase in myogenin mRNA levels. These data suggest that thoracotomy had an influence on the mRNA expression of the myogenic regulatory factors, Id-1 and Id-2 proteins. The slight changes in mRNA levels observed after emphysema were more pronounced after sham. The differences between emphysema with and without sham operation as a whole, however, were subtle. The operation itself may have an impact on the bony thorax configuration, which in turn may influence respiratory muscle function and geometry. Although the decline in the MyoD/myogenin ratio in sham animals was more accentuated after LVRS, this ratio did not differ significantly between the two groups. Not surprisingly, differences at the fibre shift level were not detected [3].

The decrease in the $\mathrm{MyoD} / \mathrm{myogenin}$ ratio is in line with the findings of Kraus and Pette [25] who demonstrated a decrease in MyoD mRNA levels and an increase in myogenin expression levels in muscles of rats subjected to hypothyroidism and lowfrequency stimulation, i.e. treatments that are known to induce fast to slow fibre transitions [26]. Moreover, MyoD is known to be predominantly expressed in fast-twitch muscles, while myogenin is prevalent in slow-twitch muscles [7, 27, 28]. There is accumulating evidence for the hypothesis that the change in the $\mathrm{MyoD} /$ myogenin ratio may be one of the driving forces behind the fibre shift [7, 8, 28]. Indeed, it was reported that alteration of the fast/slow fibre-type distribution by thyroid hormone treatment or by cross-reinnervation was always accompanied by a corresponding alteration in the MyoD/myogenin mRNA expression pattern in rat hindlimb muscle [28]. In addition, the study of MozDzIAK et al. [8] revealed that the ratio MyoD/myogenin could be important in the phenotypic transition of muscle fibres after rat hindlimb suspension. Finally, a study by SEWARD et al. [9] reported that the correlative relationship between MyoD expression and myofibre phenotype appears to be causative in the mouse diaphragm and some other skeletal muscles.

Since the observed fibre shift is likely to be related to the load placed on the diaphragm, it appears logical that the MyoD/myogenin ratio is also related to the load. The present study demonstrates a linear decline of this ratio from control, emphysematous to sham and LVRS animals (fig. 5). Consequently, at the molecular level, LVRS does not appear to exert beneficial effects on the diaphragm of emphysematous hamsters. This observation is in accordance with the results of the authors previous study, where LVRS did not improve diaphragm contractile properties [3]. If LVRS were beneficial for the diaphragm of emphysematous hamsters, an increase in the MyoD/ myogenin ratio and a reversal of the fibre shift observed in emphysematous hamsters would have been expected. This was clearly not the case.

Neither the diaphragm of emphysematous hamsters, nor that of the LVRS animals showed alterations in the mRNA levels of myf-5 and MRF4 in this study, suggesting that neither factor plays an important role in the diaphragm fibre-type shift, observed in this model. However, the expression of the myogenic regulatory factors and the Id-proteins appeared to be time dependent [7, 12]. Consequently, this could explain why MRF4 and myf-5 mRNA changes in the diaphragm, at the time of sample collection, were not observed.

Id-1 and Id-2 mRNA levels of the diaphragm decreased after emphysema, sham and a fortiori after LVRS in this hamster study. The relationship between Id-proteins and muscle fibre-shift has not been thoroughly studied yet and literature on this topic is scarce. Kraus and PetTe [25] did not observe a change in Id-1 mRNA in skeletal muscles of rats subjected to hypothyroidism and low-frequency stimulation, i.e. a model for fast-to-slow fibre transition. At present, the little that is known about the relationship between Id-proteins and muscle plasticity, mainly focuses on peripheral muscles. GUNDERSEN and Merlie [29] found a three-fold increase of Id-1 mRNA levels in rat hindlimb muscles 4 days 
after denervation. Similar results were obtained by ADAms et al. [12] reporting peak levels of Id-1 mRNA 2 months after denervation of rat hindlimb muscle. Furthermore, the muscle type, as well as the model for muscle plasticity and the timing of investigation are key determinants for the regulation of Id mRNA levels, which could be responsible for the controversial data seen between different studies. The observed down-regulation of these inhibiting factors in the present study may facilitate the diaphragm adaptation to overload.

Unfortunately, the authors were not able to perform analysis at the protein level. Since hamsters do not belong to the routinely used laboratory animals like rats and mice, only few hamster-specific products are developed by biomolecular industry. Consequently, there were no hamster-specific antibodies available for the Id-proteins and the myogenic regulatory factors.

In the present study, IGF-I mRNA levels tended to decrease in the diaphragm after emphysema (-44\%), sham $(-74 \%)$ and LVRS $(-59 \%)$, but did not reach statistical significance. This probably resulted from: 1) the high interindividual variability and 2) the relatively small sample size per group. Only few data are present concerning the relationship between IGF-I and changes in muscle fibre phenotype. YANG et al. [14] reported that passive stretch of rabbit hindlimb muscles induced an increase in IGF-I mRNA within the individual muscle fibres, which was accompanied by an increase of fibres expressing slow myosin. As for the myogenic regulatory factors and the Idproteins, muscle type and model for fibre switching are important determinants for the kinetics of IGF-I.

To conclude: 1) the decreased MyoD/myogenin ratio after emphysema, sham and lung volume reduction surgery may contribute to the fibre shift in the diaphragm, 2) the decreased MyoD/myogenin ratio in lung volume reduction surgery animals suggests that lung volume reduction surgery enhances rather than diminishes the load placed on the diaphragm and 3) the observed down-regulation of the inhibiting factors may facilitate the diaphragm adaptation to overload.

\section{References}

1. Hamacher J, Russi EW, Weder W. Lung volume reduction surgery: a survey on the European experience. Chest 2000; 117: 1560-1567.

2. Celli BR. Lung volume reduction surgery, where are we now? Eur Resp Rev 2000; 10: 343-348.

3. Marchand E, De Leyn P, Gayan-Ramirez G, Palecek F, de Bock V, Dom R, Decramer M. Lung volume reduction surgery does not improve diaphragmatic contractile properties or atrophy in hamsters with elastase-induced emphysema. Am J Respir Crit Care Med 2000; 162: 1052-1057.

4. Levine S, Kaiser L, Leferovich J, Tikunov B. Cellular adaptations in the diaphragm in chronic obstructive pulmonary disease. N Engl J Med 1997; 337: 1799_ 1806.

5. Edmondson DG, Olson EN. Helix-loop-helix proteins as regulators of muscle-specific transcription. $J$ Biol Chem 1993; 268: 755-758.

6. Murre C, McCaw PS, Vaessin H, et al. Interactions between heterologous helix-loop-helix proteins generate complexes that bind specifically to a common DNA sequence. Cell 1989; 58: 537-544.

7. Voytik SL, Przyborski M, Badyla SF, Konieczny SF. Differential expression of muscle regulatory factor genes in normal and denervated adult rat hindlimb muscles. Dev Dyn 1993; 198: 214-224.

8. Mozdziak PE, Greaser ML, Schultz E. Myogenin, MyoD, and myosin heavy chain isoform expression following hindlimb suspension. Aviat Space Environ Med 1999; 70: 511-516.

9. Seward DJ, Haney JC, Rudnicki MA, Swoap SJ. bHLH transcription factor MyoD affects myosin heavy chain expression pattern in a muscle-specific fashion. Am J Physiol Cell Physiol 2001; 280: C408-C413.

10. Langlands K, Yin X, Anand G, Prochownik EV. Differential interactions of Id proteins with basichelix-loop-helix transcription factors. $J$ Biol Chem 1997; 272: 19785-19793.

11. Benezra R, Davis RL, Lockshon D, Turner DL, Weintraub $H$. The protein Id: a negative regulator of helix-loop-helix DNA binding proteins. Cell 1990; 61: 49-59.

12. Adams L, Carlson BM, Henderson L, Goldman D. Adaptation of nicotinic acetylcholine receptor, myogenin, and MRF4 gene expression to long-term muscle denervation. J Cell Biol 1995; 131: 1341-1349.

13. Dupont-Versteegden EE, Houle JD, Gurley CM, Peterson CA. Early changes in muscle fiber size and gene expression in response to spinal cord transection and exercise. Am J Physiol 1998; 275: C1124-C1133.

14. Yang H, Alnaqeeb M, Simpson H, Goldspink G. Changes in muscle fibre type, muscle mass and IGF-I gene expression in rabbit skeletal muscle subjected to stretch. J Anat 1997; 190: 613-622.

15. Loughna PT, Mason P, Bates PC. Regulation of insulin-like growth factor 1 gene expression in skeletal muscle. Symp Soc Exp Biol 1992; 46: 319-330.

16. DeVol DL, Rotwein P, Sadow JL, Novakofski J, Bechtel PJ. Activation of insulin-like growth factor gene expression during work-induced skeletal muscle growth. Am J Physiol 1990; 259: E89-E95.

17. Adams GR, McCue SA. Localized infusion of IGF-I results in skeletal muscle hypertrophy in rats. $J$ Appl Physiol 1998; 84: 1716-1722.

18. Gayan-Ramirez G, Vanderhoydonc F, Verhoeven G, Decramer M. Acute treatment with corticosteroids decreases IGF-1 and IGF-2 expression in the rat diaphragm and gastrocnemius. Am J Respir Crit Care Med 1999; 159: 283-289.

19. Koo KW, Leith DE, Sherter CB, Snider GL. Respiratory mechanics in normal hamsters. $J$ Appl Physiol 1976; 40: 936-942.

20. Chirgwin JM, Przybyla AE, MacDonald RJ, Rutter WJ. Isolation of biologically active ribonucleic acid from sources enriched in ribonuclease. Biochemistry 1979; 18: 5294-5299.

21. Karlinsky JB, Snider GL. Animal models of emphysema. Am Rev Respir Dis 1978; 117: 1109-1133.

22. Sullivan KJ, Fournier M, Lewis MI. Respiratory work in elastase treated hamsters. Respir Physiol 1998; 114: 133-142.

23. Fournier M, Lewis MI. Functional, cellular, and biochemical adaptations to elastase-induced emphysema 
in hamster medial scalene. J Appl Physiol 2000; 88: $1327-1337$.

24. Mercadier JJ, Schwartz K, Schiaffino S, et al. Myosin heavy chain gene expression changes in the diaphragm of patients with chronic lung hyperinflation. Am J Physiol 1998; 274: L527-L534.

25. Kraus B, Pette D. Quantification of MyoD, Myogenin, MRF4 and Id-1 by reverse- transcriptase polymerase chain reaction in rat muscles-effects of hypothyroidism and chronic low-frequency stimulation. Eur J Biochem 1997; 247: 98-106.

26. Kirschbaum BJ, Kucher HB, Termin A, Kelly AM, Pette D. Antagonistic effects of chronic low frequency stimulation and thyroid hormone on myosin expression in rat fast-twitch muscle. J Biol Chem 1990; 265: 13974-13980.

27. Hughes SM, Chi MM, Lowry OH, Gundersen K. Myogenin induces a shift of enzyme activity from glycolytic to oxidative metabolism in muscles of transgenic mice. J Cell Biol 1999; 145: 633-642.

28. Hughes SM, Taylor JM, Tapscott SJ, Gurley CM, Carter WJ, Peterson CA. Selective accumulation of MyoD and Myogenin mRNAs in fast and slow adult skeletal muscle is controlled by innervation and hormones. Development 1993; 118: 1137-1147.

29. Gundersen K, Merlie JP. Id-1 as a possible transcriptional mediator of muscle disuse atrophy. Proc Natl Acad Sci USA 1994; 91: 3647-3651. 